\title{
Body and Soul in Aristotle
}

\section{Richard Sorabji}

\section{PART I : Aristotle's View}

(i) Interpretations of Aristotle's account of the relation between body and soul have been widely divergent. At one extreme, Thomas Slakey has said that in the De Anima 'Aristotle tries to explain perception simply as an event in the sense-organs'. ${ }^{1}$ Wallace Matson has generalized the point. Of the Greeks in general he says, 'Mind-body identity was taken for granted. ... Indeed, in the whole classical corpus there exists no denial of the view that sensing is a bodily process throughout'. ${ }^{2}$ At the opposite extreme, Friedrich Solmsen has said of Aristotle's theory, 'it is doubtful whether the movement or the actualization occurring when the eye sees or the ear hears has any physical or physiological aspect.'3 Similarly, Jonathan Barnes has described Aristotle as leaning hesitantly towards the view that desire and thought are wholly non-physical. But on the emotions and sense-perception, Barnes takes an intermediate position. Aristotle treats these, he says, as including physical and non-physical components. ${ }^{4}$ Other writers too have sought a position somewhere in the middle. Thus G. R. T. Ross concedes that we find in Aristotle 'what looks like the crudest materialism'. It appears that objects produce changes in an organism, 'and the reception of these changes in the sense organ is perception'. But, he maintains, this gives us only half the picture. The complete theory 'may in a way be designated as a doctrine of psychophysical parallelism'.5 W. D. Ross also seeks a middle position. He thinks that Aristotle sometimes brings out 'the distinctively mental, non-corporeal

1 Thomas Slakey, 'Aristotle on Sense Perception', The Philosophical Review (I96I), p. 470.

2 Wallace I. Matson, 'Why Isn't The Mind-Body Problem Ancient?', in Mind, Matter and Method, ed. Feyerabend and Maxwell (University of Minnesota, I966), p. 93.

3 Friedrich Solmsen, 'Greek Philosophy and the Discovery of the Nerves', Museum Helveticum ( $196 \mathrm{I}$ ), p. 170. He continues, "Nor does the "common sense" which receives, collects and synthesizes depend for its functioning on any physiological process'. He does, however, find (and write illuminatingly about) a physiological process that occurs at a different stage in perception.

4 Jonathan Barnes, 'Aristotle's Concept of Mind', Proceedings of the Aristotelian Society (1971-1972).

5 G. R. T. Ross, De Sensu et De Memoria (Cambridge, 1906), Introduction, pp. $5-7$. 


\section{Richard Sorabji}

nature of the act [of sensation]. . . . But Aristotle cannot be said to hold successfully to the notion of sensation as a purely mental activity having nothing in common with anything physical. He is still under the influence of earlier materialism'. 6

The most popular alternatives have been to regard Aristotle as some kind of materialist, or as some kind of Cartesian. But, as we shall see, there have been other assimilations. I believe that all these interpretations are mistaken, and that Aristotle's view is something sui generis. It is not to be identified with the positions of more recent philosophers. Moreover, when we see what his view is, we shall find that it has interesting implications of its own. But first, by way of background information, I must make two preliminary points about Aristotle's concept of the soul.

(ii) Preliminaries: the soul as capacities. Aristotle sometimes thinks of the soul as a set of capacities, such as the capacity for nutrition, the capacity of sense-perception and the capacity for thought. These capacities are not a mere conglomeration, but are related to each other in intimate ways, so as to form a unity. The lowest capacity (nutrition) can exist without the higher ones, but not vice-versa.

According to Aristotle's best-known definition, the soul is the form, or first actuality, of a natural body with organs ( $D A$ II. I, 412ar9; b5). But it is not always noticed that he regards this definition as insufficiently informative. He calls it an 'impression' or 'sketch', and a 'very general statement'. But it would be ridiculous, he says, to give a general definition of the soul, to the neglect of definitions that pick out the particular kinds of soul, the soul of a plant, a beast, or a man (DA II. 1-3, 412a7; b4; bro; 4I3a9-10; 414 b25-8; b32-3). An account that does pick out the various capacities by which living things differ from each other will in fact be the most appropriate account of the soul ( $D A$ II .3, 4I 5a 12-13). And with this statement at the end of $D A$ II.3, he provides the plan of the rest of the De Anima. For the rest of the work considers in turn the capacity for nutrition, the capacity of sense-perception, the related capacity of imagination, the capacity for thought, and the capacity for voluntary movement.

Aristotle's statement, that the most appropriate account of the soul is the one which picks out these capacities, already suggests the thought that perhaps the soul just is these capacities. This thought is confirmed when we notice that Aristotle speaks of the capacities as parts of the soul (e.g. $D A$ 413b7; b27-32; 429aro-13; 432ar9; $D M$ 449b5; 450a17). It is confirmed again when, using one of his technical terms, Aristotle calls the soul a first actuality ( $D A$ 412a22-8). For a first actuality is also describable as a second potentiality $\left(D A 4^{1} \mathrm{I}^{\mathrm{a} 2 \mathrm{I}}-\mathrm{b} 2\right)$, in other words as a capacity.

6 W. D. Ross, Aristotle (Methuen, 1923; Meridian Books edition, 1959), p. 135 . 
The interpretation is also confirmed by Aristotle's claim that the relation of soul to body is parallel to that of sight to the eye.?

I shall follow Aristotle below, by thinking of the soul as a set of capacities. The conception does, incidentally, have one great advantage, namely that we undeniably have a soul of the kind Aristotle describes. At least, we have a soul, if this means that we have the capacity to grow, perceive and think. But it must be admitted that Aristotle sometimes adds the difficult idea that we have a capacity to perceive and grow which explains our perceiving and growing. ${ }^{8}$

(iii) Preliminaries: the biological conception of the soul. The word 'soul' may sound archaic to some modern ears, and people may be tempted to substitute the word 'mind'. But then they are likely to confine the functions of the soul to what we call mental acts, and this will take them away from Aristotle's conception of the soul. In all this, people have been influenced by Descartes. He explains that previously the word 'soul' (anima) had been applied to the principle of nutrition as well as to the principle of consciousness (cogitatio). But he will use the word only for the latter, and, to avoid confusion, will, whenever possible, substitute the word 'mind' (mens). ${ }^{9}$

Aristotle's conception of the soul is much broader than this. He takes the view which Descartes castigates, that the nutritive processes are a function of the soul. Plato and others had attributed a soul to plants. ${ }^{10}$ Plato had

${ }^{7} D A$ 4rabi7-4r3a3. Willie Charlton and Professor Wiggins have pointed out that Aristotle sometimes thinks of the soul as that which has capacities, i.e. the person (Charlton, Aristotle's Physics Books I and II (Oxford, 1970), pp. 70-73; Wiggins, Identity and Spatio-Temporal Continuity (Blackwell, 1967), part 4, sec. 2). This observation is illuminating, especially for the study of Metaphysics, Book VII. But it must be insisted that sometimes, and in the De Anima often, Aristotle thinks of the soul as being the capacities themselves. He is not thinking of the soul as that which has capacities, when he says that a person is angry with his soul ( $408 \mathrm{bI}-\mathrm{I} 5)$, or that the soul is the cause of living, and the efficient cause of perception and growth, and that only what partakes of soul perceives (4I $5 \mathrm{~b} 8-28$

${ }^{8}$ It is easy to understand Aristotle's idea that our capacity for desire explains our moving from place to place ( $D A$ III.9-10). But it is harder to see how the capacity to perceive can explain our perceiving, or how the capacity to retain a certain distinctive organization while we grow can explain our retaining this organization while we grow $\left(D A 4^{1} 5^{\mathrm{b} 23-28} ; 4^{16 a 8}-9 ;\right.$ b2I-22).

${ }^{9}$ Reply to objections brought against the 2nd Meditation, $\S_{4}$, in the $5^{\text {th }}$ Objections, translated Haldane and Ross, vol. II, p. 210.

10 Plato Timaeus $77 \mathrm{~A}-\mathrm{B}$. Empedocles believed he had in a previous incarnation been a bush (fragment II 7 in Diels, Die Fragmente Der Vorsokratiker). It may have been because of his belief that souls could be reincarnated in plants that Empedocles forbade the eating of beans (fr. 14I). But members of the Orphic sect allowed that some or all vegetable food lacked a soul (Euripides, Hippolytus 952). 


\section{Richard Sorabji}

coupled this view with another current view, that plants had sensations and desires. ${ }^{11}$ Aristotle retains the first idea, that plants have souls, but sensibly rejects the second, that they have sensations and desires. Instead, he makes sensation the distinguishing mark of animals. But how, then, does he justify continuing to attribute a soul to plants? By extending the concept of soul, so that the non-conscious processes of nutrition and growth will now count as an activity of the soul. This extension may sound strange to us. But appeal to a (non-conscious) soul is needed, Aristotle thinks, to do justice to such facts as that a plant does not expand haphazardly, but preserves, or develops, a certain distinctive organization. ${ }^{12}$ The resulting conception of the soul makes it coextensive with life, that is, with all life. The conception of soul is a biological one, and it encourages Aristotle to stress the continuity, rather than the differences, between processes in plants and processes in humans. Descartes was wrong, in the passage referred to at the beginning of this paragraph, when he ascribed the connection between the soul and nutritive processes to the earliest men. The connection is in fact an innovation of Aristotle's, though it may well be true that Aristotle's predecessors, other than Plato, already ascribed to the soul functions which were not mental ones. ${ }^{13}$

Though Aristotle makes plant growth a function of the soul, he does not take the next step. He does not attribute the movements of earth, air, fire

11 Plato Timaeus 77A-B. Put into the mouth of Protagoras by Plato, Theaetetus ${ }_{1} 67$ B. Asserted, if we can believe our late sources, by Empedocles, Democritus and Anaxagoras (see pseudo-Aristotle, De Plantis 81 5ar6; br6; Sextus Empiricus, $A d v$. Math. VIII, 286, using as evidence Empedocles, fr. I Io. Cf. fr. 103).

12 See, e.g. $D A$ 416a6-9. A plant also produces seed for the next generation. And this must be done by converting the nutriment it draws from the soil (see G. $\mathbb{E}^{\circ} C$. I. $5 ; D A$ II.4).

An excellent account of Aristotle's biological extension of the concept of soul is given by Solmsen in the American fournal of Philology, loc. cit., note 69 below.

${ }^{13} \mathrm{~A}$ major function of the soul, among early Greek philosophers, was to cause motion (DA 403b26; 405 bI ; 409bI9). Did the soul always cause motion by means of some mental activity? Aristotle implies not in the case of Democritus (DA 406b24-25), though in this particular instance Aristotle's testimony is suspect. According to another conception, the function of the soul was not connected with consciousness in this life, but was simply to survive, perhaps with a very low level of consciousness, when a man died (see R. B. Onians, The Origins of European Thought (Cambridge 195I), for such a conception in Homer).

For Plato, one function of the soul was to cause motion, but it caused motion by means of some mental activity (Laws $896 \mathrm{E}-897 \mathrm{~A}$ ). I do not believe that Timaeus $36 \mathrm{E}$ says otherwise. 
and water to a soul within them, ${ }^{14}$ presumably because the four elements are lifeless things. But although the four elements do not have souls to move them, there are analogies between the movement of elements, the growth of plants, and the movement of animals. All three are processes directed towards an end, and all three are due to nature, which in Physics II. I is defined as an internal cause of change (192b2o). There is the difference that the nature, or internal cause, is not a soul or a desire, in the case of the four elements. But this only raises the question how the nature that resides in the elements differs from a plant soul or from the desire of animals, a difficult question which we shall encounter again (p. 83). The Physics offers no satisfactory answer, but an answer can be pieced together from Aristotle's later works. ${ }^{15}$

(iv) The contrast with Descartes. We can now return to the rival interpretations of the body-soul relation in Aristotle. Some of the interpretations

14 Aristotle would have had some precedent, if he had attributed the motion of the elements to desire or to a soul. For Empedocles spoke of the four elements moving on account of desire or love for each other (frr. $21.8 ; 22.5 ; 62.6$ ). Plato's Timaeus (52D-53A) allowed movement of the four elements, without the presence of soul, his Laws (897A) was ambiguous on the point, but his Phaedrus $(245 \mathrm{E})$ declared that whatever has an internal source of motion is ensouled. In a later age, Descartes was to complain that the scholastic tradition had created in the concept of gravity a sort of pseudo-soul (Reply to 6th set of Objections, sec. Io, HR. vol. II, pp. 253-257. For Descartes' own view, see Principles of Philosophy III. 56 and IV. 20-27). But this was neither the fault of Aristotle, nor of St. Thomas Aquinas. For though St. Thomas speaks of the four elements moving on account of desire (desiderium, appetitus) for their preservation (Commentary on Aristotle's Physics 208b9, and Summa Theologiae Ia II $\left.{ }^{\mathrm{ae}}, \mathrm{q} .94, \mathrm{a} .2\right)$, he carefully explains away a similar way of talking about the desire (appetitus) of matter for form (Commentary on Aristotle's Physics 192a22).

15 The Physics hints at analogies (192a22; 250br4). But it fails completely when it tries to spell out the disanalogies (255a5-20; b29-31). A good account of this failure is again given by Solmsen in Aristotle's System of the Physical World, loc. cit., note 69 below.

According to later writings, desire in animals differs from the nature of a stone, in that it involves a physiological process in virtue of which desire is a cause of motion ( $D A$ I. I Mot. 6-10). It also differs in being intimately linked with other soul capacities, with nutrition, which maintains the organs in the right state, and with perceiving, imagining, conceiving and judging. For (Mot 6-8; II; DA III.9-II) an animal must perceive, imagine, or conceive the end desired, and, in some cases, the means to its realization. A human being may also make a judgment that the end or means conceived is to be pursued, or not. Desire differs again, in that desires have varying ends (Metaph. IX.5; Cael. II. I2), some of them conflicting ( $N E$ VII.3, Bekker's numbering), some changeable by training ( $N E$ II.I), some being only apparent goods, not real goods (NE III.4). 


\section{Richard Sorabji}

attribute to Aristotle a Cartesian strand. Solmsen and Barnes attach importance to the fact that Aristotle makes perception an act of the soul. But given Aristotle's biological conception of the soul (which Solmsen has done so much to bring out), this tells us that perception manifests life, not that it manifests consciousness. G. R. T. Ross finds significance in Aristotle's calling perception an energeia and entelecheia. But when Aristotle insists that perception is an energeia and an entelecheia, rather than a pathos (DA 417a14-16; b2-12), he has in mind that it is an actualization of a disposition and that the subject of this actualization is not destroyed but preserved and fulfilled. When Aristotle says that perceiving is an energeia, rather than a kinesis (Metaph. 1048b18-36; NE 1 174ar 4-b9; DS 446b2-3), he means that processes are incomplete until they reach their end, but with activities like perceiving one can say 'I have perceived' right from the very beginning. These points do not imply that perceiving is 'something mental' (p. 5) or 'an act of mind' (p. 6). Living can be called an energeia, even when we are talking of the non-mental life of a plant. W. D. Ross attaches importance to the passage we shall discuss below where Aristotle says that smelling is something else besides (para) a physical change ( $D A$ 424a32bi 8). But Ross assumes without warrant that if there is 'something else', it can only be conceived of as distinctively mental. His second piece of evidence is that Aristotle sometimes speaks of perception as involving discrimination. But here too Ross assumes without warrant that discrimination can only be conceived of as something distinctively mental.

Turning to the case on the other side, we should notice that Aristotle has no word corresponding to 'mental act', or to Descartes' cogitatio (consciousness). Charles Kahn has suggested that the nearest word is aisthanesthai (perceiving), for this covers a very wide range of mental acts. ${ }^{16}$ Nonetheless, as Kahn carefully points out, the word does not correspond to Descartes' cogitatio, for Aristotle draws a sharp distinction between thinking and perceiving. He never suggests that thinking is a kind of aisthanesthai. Nor, as we shall see, does he say of aisthanesthai the sort of things that Descartes says of cogitatio.

In a very un-Cartesian way, Aristotle insists that, in some sense of 'is', every mental act is a physiological process. Thus anger is a boiling of the blood or warm stuff around the heart, in a sense of 'is' analogous to that in

16 In Aristotle, pleasure and pain ( $P A$ 666a12), awareness of memory-images (DM 45 ob 14; 16; 18;28); awareness of one's own acts of sense-perception (Som. 455aI7; DA 425br2; NE II70a29-br); awareness of being asleep (Insom. 462a3). In other authors, desire, fear, and intellectual discernment. For the reference to Kahn's article (which is basic reading for this subject), see note 69 . 
which a house is bricks $(D A 403 \mathrm{az} 5-\mathrm{b} 9) .{ }^{17}$ The point is made about all pathe of the soul, the examples in this chapter being anger and calmness, confidence and fear, loving and hating, appetite, pity and joy. ${ }^{18}$ And it is also made about two activities that Aristotle hesitates ${ }^{19}$ to call pathe, perception and thought, though it is at first made only tentatively 20 about thought. The point is not made about long-term states (hexeis), or capacities (dunameis) of the soul. ${ }^{21}$ And at one place Aristotle says it is thought to be a mark of the pathe $\bar{e}$ rather than of the hexeis that they are corporeal $(N E$ I r 28b14-15). Nonetheless, he does often speak as if hexeis and dunameis too had some kind of physiological basis. ${ }^{22}$

The statement that anger is a physiological process does not initially sound very Cartesian. But Cartesian interpreters of Aristotle may take

${ }^{17}$ Aristotle does not list this as a distinct sense of 'is', when he talks about the different senses of the verb to be. But he still treates this use of 'is' in a distinctive way. He notes that ordinary speakers prefer to say that a thing is composed of wood (Metaph. r033ar6-19), or better (1033ar9-22) is wooden, rather than that it is wood. And he has reasons of his own, to be discussed on p. 78 , for doing likewise, and refusing to say that a thing is its matter (Metaph. 1035a7-10; 104rbi2I6).

18 Other examples of pathe of the soul are envy, emulation, longing, shame and shamelessness, kindness and unkindness, and indignation at unmerited prosperity (NE I 105b19-28; I 128b9-15; Rhet. II. 2-I ; $E E$ 1220bro-20). The semiphysiological analysis is mentioned also at $D S 436$ a6-10; bI-8; $D M$ 450a27-30; Som. 454a7-II, and is connected with yet other mental states, desire in general, pleasure and pain, memory and memory images.

For the claim that anger is a bodily process, see $D A$ 403a26. In making all pathe of the soul physiological, Aristotle is rejecting the claims of Plato Philebus $34 \mathrm{~B} ; 35^{\mathrm{C}} ;{ }_{47} \mathrm{E}$.

${ }^{19}$ See $403^{\mathrm{a} 3}$ for the name pathē. But Aristotle sometimes prefers to talk of them as things the soul does (poiein 403a7), or as functions of the soul (erga 403aro).

20 Eventually it emerges that all human, as opposed to divine, thinking involves imagery, and hence a physiological process $(D A$ 43rar6; b2; 432a8; ar3; $D M 449 \mathrm{~b} 3 \mathrm{r})$.

21 For the distinction see $N E$ Iro5br9-28; Iro6a3; a5; II 57b28-31; $E E$ 122obr3-14; Rhet. 1378a2o; Cat. 8b26-9ar3; 9b33-10aro. Pathé of the soul (e.g. anger) are accompanied by pleasure or pain, and affect one's judgment. We are said to undergo change (kineisthai) when we have them. They are not the result of deliberate choice. They are comparatively short-lived and easily removed. A hexis of the soul (e.g. good temper) is something in accordance with which we are well or ill disposed in relation to pathē. A dunamis of the soul (e.g. the ability to be angry) is that in accordance with which we are capable of suffering pathe

22 For examples, see Theodore Tracy, Physiological Theory and the Doctrine of the Mean in Plato and Aristotle (Mouton, 1969), passim; Sorabji, Aristotle on Memory (Duckworth, 1972), notes on $449 \mathrm{b6}$ and 453 arg. 


\section{Richard Sorabji}

courage from Aristotle's insistence that the physiological process is only the matter, or material cause, of anger. There is also a form, or formal cause, namely the desire to retaliate. And anger can be said to $b e^{23}$ this formal cause, or desire, just as a house can be said to be a shelter. This statement in 403a25-b9 is reinforced at $424 b_{3}-18$, where Aristotle says that exercising smell is something else besides (para, 424br 7-19) merely being affected by something. It is also a matter of aisthanesthai. In view of the wide use of aisthanesthai, we may take the word as meaning awareness. And we may take the point to be that smelling is not simply a matter of being affected by odour, but is also an awareness of odour. The Cartesian interpreter might now read into these two passages the idea that anger or smelling has two components (cf. Barnes pp. 107; I13). The physiological process is one component; the other is a purely mental act of desire or awareness.

This interpretation is impossible for two reasons. First, the form of a thing is not a component in it. A shelter is not a component in a house. Aristotle explains this carefully in the Metaphysics. His examples are a syllable, a house, and flesh. These are composed respectively of letters, of bricks, and of the four elements. But the form is not a further component. The arrangement of the letters $B$ and $A$, for example, is not a component in the syllable BA (Metaph. I04Ibrg-33; 1043b4-6). On the contrary, it is matter, not form, which constitutes the components. This is how matter is defined (Phys. 195a 19; Metaph. ro32a17). There is a second objection to the Cartesian interpretation. Even if there had been a component in anger other than the physiological process, that component could not have been a purely mental act. For Aristotle, no acts are purely mental, since every pathos of the soul is, among other things, a physiological process.

The Cartesian interpreter must not look, then, for a purely mental component in anger. His only hope lies in finding Aristotle treating anger as a whole as a distinctively mental act, in spite of its also being a physiological process. But it is no longer very clear what it means to call something distinctively mental, if one is at the same time calling it physiological. It is true that many recent materialists, in talking of the identity of mental states and brain states, have spoken as if this were possible. But Richard Rorty is right in taking them to task. ${ }^{24}$ The materialist view, as he points out, should be expressed by saying, "what we thought to be mental acts may after all be physiological processes instead'. If one calls anger a physiological process, one cannot continue to call it distinctively mental. Or if one does, one is departing from a Cartesian concept of mental acts, and will then have to explain what one means by 'mental'. For Descartes, mental

23 A pathos of the soul is an enmattered form (403a25), just as a house is a form (403 b6). Again, anger is a movement of a faculty (desire?), as well as being a physiological movement (403a26-27).

24 Richard Rorty, 'Incorrigibility as the Mark of the Mental', The fournal of Philosophy (1970), esp. pp. 399-406. 
activities have no affinity (affinitas) with bodily activities. ${ }^{25}$ And the mind itself has properties which are actually incompatible with those of the body, for the body is extended and divisible, the mind neither extended nor divisible. ${ }^{26}$

Aristotle is unlike Descartes in several fundamental ways. For one thing, the topic of self-awareness does not play the same role in his account of the soul. Descartes defines the mind as a conscious being (2nd Meditation, HR I, p. I 52), and consciousness (cogitatio) as 'all that is in us in such a way that we are immediately aware (conscii) of it'. ${ }^{27}$ Because of this, the notion of self-awareness is central in Descartes' view of the soul. But Aristotle's remarks on self-awareness are brief, sporadic, and by no means centrally placed. The topic did not have the same interest for him. His most Cartesian remark is perhaps the one in the Physics, when he says that a change of quality in the sense-organs of a living thing differs from a change of quality in a lifeless thing, in that it does not go unnoticed (Phys. 244br 5-245az). He also suggests, though sometimes only in an 'if-' clause, that one is inevitably aware of one's own perceiving, thinking, and remembering ( $D S$ 437a27-9; 448a26-8; $D A$ 425b 2 ; $N E$ I 1 70a29-br; $D M 452 \mathrm{~b} 26-8)$. But in several ways Aristotle's remarks on self-awareness are unlike Descartes'. First, he does not seem to hold consistently to the claims about self-awareness that we have just referred to. ${ }^{28}$ Secondly, he is just as ready to entertain the idea that one is inevitably aware of one's own walking ( $N E$ I 1 70230$)$. And there is no attempt to make self-awareness a distinguishing mark of mental acts, by protesting, with Descartes, that awareness of one's own walking is not immediate (loc. cit. note 27), or by distinguishing between the corporeal act of walking and merely seeming to walk. ${ }^{29}$ Thirdly, Aristotle's view of how one is aware of one's own seeing is rather surprising. For $D A 425$ br 2-25 equates the question of how we are aware that we are seeing (425bi2; br 3 ), or, in other words, how we are aware of our sight $\left(425 \mathrm{bl}_{1} ; \mathrm{br} 6\right)$, with the question of how we are aware of the organ that sees (to horon, 425b19; b22). This implies that it is through

${ }^{25}$ Reply to objection on the 2nd Meditation, in the 3 rd set of Objections, HR II, p. 64 .

${ }^{26} 6$ th Meditation, HR I, pp. I9o and 196, and Passions of the Soul, article 30, HR I, p. 345 .

${ }^{27}$ Reply to and Objections, Definition I, see HR II, p. 52.

${ }^{28}$ Processes (kine éseis) in the sense-organs, and images (phantasmata) can after all pass unnoticed, according to Insom. 460b28-46ra8; 46rarg-22, and according to an argument (whose conclusion, however, Aristotle rejects) at $D S$ 447aI2-b6. Moreover, $D M{ }_{45}$ 1a2-5 admits that a man may be remembering, in spite of being in doubt whether he is.

29 2nd Meditation, HR I, p. 153; Principles of Philosophy I.9, HR I, p. 222; Reply to objections on the 2nd Meditation, $\$ ₫$ I and 9, in the Replies to the 5th Objections, HR II, pp. 207 and 213. 


\section{Richard Sorabji}

awareness of the organ that we are aware that we are seeing. He goes on to remind us that the organ is coloured during the perceptual process $(425 \mathrm{b22}-$ $25),{ }^{30}$ and presumably we will be aware of its coloration. ${ }^{31}$ This coloration is a physiological process, which could in principle, even if not in practice, be seen by other observers, using ordinary sense-perception. So what one is aware of on these occasions does not sound like a Cartesian act of mind. The only concession to a Cartesian way of thinking - and it is not a very big concession-comes when Aristotle says that the perceiver does not simply see his own organ and act of seeing ( $D A 4_{425} \mathrm{~b}_{17-22}$; Som. 455a I7), but is aware of it in a different manner. ${ }^{32}$

There is another way in which Aristotle is fundamentally unlike Descartes. He does not divide up the world at the same points. We have already noticed that he does not treat mental acts as a single group, but makes a sharp distinction between perception and thought. Nor does he follow Descartes in trying to separate off from the group nutrition (note 9),

30 For the view that the organ takes on colour when we see, v. $D A$ 424a7-10; 425b22-24; 427a8-9; 435a22-24; 417a2o; 418a3; 422a7; 422a34; 423b3o; $424 \mathrm{ar} 8 ; 424 \mathrm{~b} 2 ; 429 \mathrm{ar} 5 ; 434 \mathrm{az}$. The first four passages suggest a literal taking on of colour. The theory has been misunderstood by modern commentators. It is

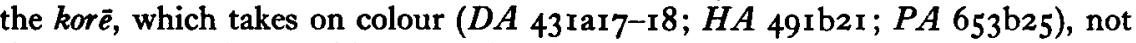
the eye as a whole, which would indeed be an absurd theory, as Professor Hamlyn and Jonathan Barnes say it is (Hamlyn, 'Aristotle's account of Aesthessis in the De Anima,' Classical Quarterly (1959), pp. 9 and I r; Aristotle's De Anima, Books II and III (Oxford, 1968), pp. 104 and II3; Barnes, op. cit., p. I09). Aristotle's theory would still be absurd, if the kore were the pupil, as all recent English translators of the psychological works suggest (Beare, Hamlyn, Hammond, Hett, Hicks, G. R. T. Ross, Smith). But the kore is in fact the eye-jelly inside the eye ( $D S 438 \mathrm{ar} 6 ; 438 \mathrm{~b} 5-16 ; H A 49 \mathrm{rb2r} ; D A$ 425a4; $G A$ 780b23). And it would not have been obvious, with the instruments available to Aristotle, that this eye-jelly did not in fact become coloured during the process of vision.

One advantage of assuming a literal taking on of colour is that this explains how shapes and sizes can be received in the organ. The coloured patches in the eye-jelly have shapes and (small-scale) sizes.

${ }^{31}$ This is part of a two-pronged answer to a puzzle set in Plato's Charmides I68D-E. Sight can't see itself, for only what is coloured can be seen. Aristotle replies (i) sight is not seen, but only perceived with the aid of sight. (ii) What is perceived on these occasions (the organ) is coloured, so on this score there would have been no barrier to its being seen.

For further references to the idea that, when seeing, one not only receives, but also perceives, processes in one's eye-jelly, v. $G A 78 \mathrm{ob}_{32}$, and (in the course of an argument whose conclusion Aristotle rejects) $D S$ 447a23-27.

32 The De Anima suggests that sight plays an indirect role in our awareness of our own seeing, just as it does in our awareness of darkness. We don't see darkness, but are aware of it through trying (and failing) to see other things. The De Somno -supplementing, but not, I think contradicting the De Anima-says that we are aware of our own seeing through the central sense-faculty (455ar 5-25). 
or in distinguishing between corporeal acts of walking or seeing, which do not belong to the group, and seeming to see or seeming to walk, which do belong (note 29). Aristotle groups together thought, perception and walking as activities of which we are conscious, and does not follow Descartes in protesting that we are not immediately conscious of corporeal walking (loc. cit. note 27). Thought, perception and walking are grouped together again, on the grounds that they all belong to humans, none to plants. And they are grouped together with each other and with nutrition, on the grounds that all are due to the soul. Admittedly, walking, weaving and building are not things the soul does, but are merely due to the soul. But $D A 408 \mathrm{br}$ I-1 5 explains that this is no less true of thinking and being angry. All are things the man does with his soul, not things the soul does.

(v) The contrast with Strawson. This may be enough to make clear that Aristotle cannot be aligned with Descartes. But it should not be thought either that he can be aligned with present-day critics of Descartes. Presentday readers may be reminded of the anti-Cartesian arguments of Strawson, ${ }^{33}$ when they see Aristotle refusing to make a sharp break between thinking or desiring on the one hand and walking, weaving, or building on the other. But Aristotle is further away from Descartes than modern critics are. For he equally refuses to make a sharp break between walking on the one hand and nutrition and growth on the other. All are equally due to the soul.

(vi) The contrast with Brentano. In 1867, Franz Brentano interpreted several Aristotelian passages as meaning that the object of sense-perception or thought is not (or not only) physically present in the observer, but present in a non-physical way as an object of perception or thought (Die Psychologie des Aristoteles, Mainz 1867, pp. 79-81 ; 86; 120 n. 23). In 1874, he suggested a new criterion of his own for distinguishing mental from physical phenomena. Mental phenomena are directed towards objects, and the objects have 'intentional inexistence'. That is to say, the object of a thought or wish exists in the mind, but does not have to have real existence outside of the mind (Psychologie vom empirischen Standpunkt, Vienna. A selection is translated as ch. I in R. Chisholm (ed.), Realism and the Background of Phenomenology, Allen and Unwin, 1960). Brentano detected in Aristotle this idea of the 'mental inherence' of objects of thought and sense-perception, and he cited some of the same passages as before (Chisholm's selection, note ${ }^{15}$ ). The first publication merely spoke of colours and temperatures being in the perceiver as objects (objectiv). The later publication filled this out, finding in Aristotle objects of the kind which Brentano believed characteristic of mental acts. In connexion with sense-perception, Brentano cited as evidence for his interpretation

3 Strawson, Individuals, Methuen 1959, ch. III, esp. §§(5)-(6). 


\section{Richard Sorabji}

Aristotle's theory that the sense-organs 'receive form without matter' ( $D A$ 424ar $8 ;$ b2 ; 425b23; 427a $8 ; 429 a 15 ; 434$ a29; 435a22), the claim that using one's senses is not the ordinary kind of paschein $(D A 4 \mathrm{I} 7 \mathrm{~b} 2-7)$, and the claim that the actualized object of sense is within the sense ( $D A$ 426a2-4).

Of the three Aristotelian ideas that Brentano cites, the first two are used also by Barnes (note 4 above), but neither idea seems to prove the point. I have already commented on the second (p. 68 above). The first concerns receiving form without matter. It is nearly ${ }^{34}$ always the sense-organ, or the perceiver, not the sense, which is said to receive form without matter. Brentano takes it in his first publication that this reception of form involves the object of perception being present in a non-physical way (pp. 8o-8I ; 86), and Barnes, following him, holds that it introduces a non-physical component into perception. But there is good reason ${ }^{35}$ to interpret the reception of form without matter physiologically. It means that e.g. the organ of sight (i.e. the jelly inside the eye, see note $3^{\circ}$ ) takes on the colour of the object seen, without taking on any material particles from the object, such as Empedocles and Democritus had postulated. In that case, in talking of the organ's reception of form without matter, Aristotle is so far talking only of the physiological process.

The third Aristotelian idea that Brentano cites suits his case best. For Aristotle does say that the actualized object of sense inheres in the sense (if we read $t \vec{e} \dot{i}$, the sense, not $t \bar{o} i$, the organ, at $426 \mathrm{a} 4$ ), and he adds that the actualized object of sense lasts only as long as the act of sensing (426a I 5-26). This fits with Brentano's first, and less explicit, claim that the object of

${ }^{34}$ The exceptions seem to be cases where Aristotle has misleadingly borrowed the terminology of form without matter, to express the quite different doctrine that the act of sensing is identical with the actualized object of sense.

${ }^{35}$ Having declined to regard the reception of form without matter as a physiological process, Barnes finds it difficult to attach any very precise meaning to the idea. In fact, the idea is connected with the organ's becoming like the object perceived ( $\left.D A 4^{29 a 1} 5^{-16}\right)$, and with the taking on of colours or temperatures (see $D A$ 424a7-10; 425b22-24; 427a8-9; 435a22-24). So it seems easier, and it is also appropriate in the historical context, to interpret the reception of form without matter in our way. This physiological interpretation has the added advantage of enabling us to understand what Slakey could not understand, the second of two explanations at $424 \mathrm{bl}-3$ of why plants cannot perceive. Plants cannot receive form without matter, i.e. they can only take on colour and warmth by admitting coloured or warm matter. Barnes' reason for refusing to regard the reception of form as a physiological process of the organ changing colour or temperature is that the resulting theory would have been 'open to devastatingly obvious empirical refutation' (p. I09). But the refutation would not have been obvious, if the organ of sight is the eye-jelly (as is argued in note 30 above), and if the organ of touch is the heart. Such organs would not have been readily open to inspection. 
perception for Aristotle is in the perceiver in a non-physical way. ${ }^{36}$ But Brentano's later interpretation seems wide of the mark. For Aristotle does not agree that the object of sense need not have real existence outside of the mind. On the contrary, the object of sense in its potential state does exist outside of the mind (426ar 5-26). Admittedly, Aristotle acknowledges that there are mental states whose objects do not really exist. A wish, for example, can be directed towards something impossible, such as immortality. But this is not true of all mental states, nor even of all kinds of desire $\left(N E\right.$ I I I I I IO-30). ${ }^{37}$

(vii) The contrast with materialism. Having failed to align Aristotle with Descartes or Brentano, we should not swing to the opposite extreme and treat him as a materialist. The fullest case for doing so was made by Slakey (note I above). But unfortunately Slakey rested his case mainly on an interpretation of $D A 423 \mathrm{~b} 27-424$ a IO which I believe to be mistaken. In this passage, Aristotle says that aisthësis is a mean or mid-point (mesotés). Slakey takes this to mean that sense (the capacity to perceive) is the capacity of the organ to change to one extreme or the other, to hot or to cold for example. He infers that sensing will simply be the process of the organ's changing to hot or cold.

In fact, however, when Aristotle talks here of aisthèsis, he seems to be concerned not (or not directly) with sense, as Slakey requires, but with the

36 Perhaps the actualized object of sense is something that we would characterize as mental. And this would support Barnes, provided he does not say that Aristotle himself would conceive the actualized object as mental. It does not support Brentano, however, for Brentano believes that only the sense is mental; its object is physical.

${ }^{37}$ Subsequent authors have offered new criteria of intentional inexistence, in order to defend Brentano's idea that mental phenomena are distinguished by having intentionally inexistent objects. 'Most of us knew in 1944 that Eisenhower was the one in command ...; but although he was (identical with) the man who was to succeed Truman ...., it is not true that we knew in 1944 that the man who was to succeed Truman was the one in command ... ., i.e. We can't substitute 'the man who was to succeed Truman' for 'Eisenhower', and Chisholm uses this non-substitutability as a criterion of intentionality (Perceiving (Cornell, 1957), p. 171). But Aristotle would not agree that such non-substitutability was confined to psychological contexts. He discusses non-substitutability in a variety of contexts, only some of them psychological. (See Soph. El. 179a26-b6; NE I135a29 on objects of knowledge; Poet. ch. 4 on enjoying a picture qua $\bar{a}$ splash of colour, while not enjoying it $q u \bar{a}$ representation; Phys. 195a27-b3o on incidental causes; Phys. 202ar9-20; bro-16 on the notions of uphill and downhill.) 


\section{Richard Sorabji}

sense-organ..$^{38}$ For he describes it as changing temperature (424a6-10). Even if he had been directly concerned with sense, he would in any case have been assimilating it hereby to the organ, and not, as Slakey suggests, to a capacity of the organ. Aristotle, I believe, is concerned in particular with the organ of touch. He argues that this organ cannot lack temperature (etc.), in the way that the eye-jelly lacks colour. (This is the relevance of 423 b27-31.) He also argues that its natural temperature is an intermediate one, mid-way between hot and cold. (This is why he calls it a mean or mid-point, 424a4.) That its normal temperature is a mean one is inferred from the supposed fact that we have a blind spot for mean temperatures (alla tôn huperbolōn, 424a4). The inability of plants to perceive is explained $\left(424 \mathrm{bI}^{2} \mathbf{4 2}^{2} \mathrm{azo}^{-} \mathrm{b}_{3}\right)$ as due to their lack of an organ of touch, which is in turn due to their being too earthy and cold to have an organ with a mean temperature. We can thus explain why Aristotle uses the word mesotès which means mid-point, how he accounts for the insensitivity of plants, and what relevance he sees in lines $423 \mathrm{~b} 27-3 \mathrm{I}$. It was a disadvantage of Slakey's interpretation that these points remained mysterious.

But even if this particular passage does not support Slakey's materialist interpretation, we ought to take his suggestion seriously. For we could well expect Aristotle to be a materialist, seeing that so many of his predecessors were preoccupied with the physiology of mental acts. Many of their statements, at least if taken in isolation, could suggest that mental occurrences are simply physiological entities. And Aristotle, along with his successor Theophrastus, and later commentators who drew on Theophrastus, often interpreted early writers in this sense. ${ }^{39}$ Moreover, many of Aristotle's own remarks, if taken in isolation, seem to suggest a materialist view. Of sense-perception he says that it is a matter of being affected by something, that it is a change in the body, that it is a qualitative change, and that a certain change in the eye is seeing. ${ }^{40}$

Even more striking is his treatment of memory-images and dream-images in the De Memoria and De Insomniis. We are given every reason to think that Aristotle is discussing what we should call a mental image. It is a

38 Either aisthesis refers to the organ here, or, if it refers to sense, the sense is called a midpoint only derivatively, because the organ is one. The sense does seem to be called a blend (logos) later at $424 \mathrm{a}_{2} ; 42 \mathrm{ab}^{2}$; $\mathrm{b}_{3}$; $\mathrm{b}_{7}$, but the point being made there is a different one which applies to senses other than touch.

39 See Metaph. Ioogbi I ff; $D A$ 427a26, on Empedocles and Democritus. Also Parmenides fr. 6, lines 5-6, and fr. I6. Empedocles fr. 105. Anaxagoras, according to Theophrastus, De Sensibus §3r. Democritus, according to Aëtius, A. $3^{\circ}$ in Diels. Some of Plato's Timaeus also lends itself to this interpretation. On Homer, see R. B. Onians, op. cit. For Aristotle's interpretation of some earlier views on pleasure, see $N E$ I $173 \mathrm{~b} 7-9$.

40 For these four statements, see (i) $D A$ 424ar ; 427a9; (ii) Phys. 244br I-12; (iii) Insom. 459 b4-5; Mot. $70 \mathrm{rbr} 8$; (iv) $G A 780 \mathrm{oa} 3$. 
phantasma, is in our soul, and is contemplated by us. ${ }^{41}$ Nonetheless, at the same time, he gives this image a very physical interpretation, insisting, for example, that the surfaces within the body must not be too hard to receive it (DM 450a3o-bro), and implying that the image does not depend for its existence on being perceived.42 At Insom. 462a8-12, he says that we can confirm that we observe processes in our sense-organs, if we attend to what happens when we are going to sleep or waking up. For sometimes on waking up, we can surprise the images (eidola) that appear to us in sleep, and find that they are processes in our sense-organs.

But these statements should not be taken in isolation. They must be read against the background of Aristotle's full theoretical statements in the De Anima. The two main theoretical statements are very prominently placed. One comes in the opening chapter of the first book (403a3-br9), the other in the closing chapter of the second book, where it rounds off the discussion of the five senses $\left(424 b_{3}-18\right)$. We should remember these fuller explanations when we encounter the more hasty expressions which we have been looking at. Of the two theoretical statements the first is that which says that the physiological process is only the material cause of anger. There is also a formal cause. The second is that which says that smelling is something else besides (para) the process of being affected by odour.

The materialist interpreter may take heart when he sees that Aristotle uses the very same kind of analogy as some modern materialists have used. Anger is a physiological process in much the same sense as a house is a set of bricks. Some modern materialists have offered the analogy of a bucket of water being a set of $\mathrm{H}_{2} \mathrm{O}$ molecules. But Aristotle is more accurate than these materialists. For they want to say that mental states may be identical

$41 D M$ 450a25-451ar7; Insom. ch.3. For the word phantasma, see DM 45obro; b24; 45rar 5 ; etc.; Insom. 46rar8; 462ar6; a29-31. For 'in the soul', see $D M$ 450a28; bro-I I; 45ra3. (The expression 'a process of the soul' would have been less significant, since it could have been applied to plant growth, as well as to a mental entity.) For reference to contemplating and perceiving the image, to taking it as resembling, or as identical with, familiar objects, to its appearing and being noticed, see $D M$ 450b15-18; 450b24-45 Ia2; Insom. 460bIo-II; b23-29; 460b31-46ra8; 46raI9-22; 462a8-I2. The significance of the last point, however, the observability of the image, will be reduced, when we recall that Aristotle sometimes speaks of our observing physiological processes within ourselves (see pp. 71-72).

42 Insom. 460b31-46ra8; 46rarg-22. A physical interpretation suggests itself also when Aristotle says that the changes left behind in us by earlier senseimages are located in the blood in our sense-organs (46rbi2; br6-19; 462a9; aI2). They can travel down with the blood towards the heart (46ra5-7; 46raz8-bi; $46 \mathrm{rbr} 2)$. They may collide with each other (46raro-ir), and change their shape (46raro-II; brg-2I) like the eddies in rivers, or like figures in clouds (46ra8-9; bI9-2I). 


\section{Richard Sorabji}

with physiological processes. Aristotle sees that, at least for some purposes, it is misleading to say that a house is identical with a set of bricks, and in general that a thing is identical with its matter. He denies that the syllable BA is, or is identical (to auto) with, the constituent letters, or that flesh is its constituent elements. And he gives the excellent reason that the components can outlast the compound. Bricks can outlast the house. ${ }^{43}$ The same reason has recently been given by Professor Wiggins for distinguishing between the relation of identity and the relation of composition.44 By noticing that, at least for some purposes, it is wrong to say that a thing is identical with its components, Aristotle improves on some present-day materialists, and on Descartes. ${ }^{45} \mathrm{He}$ often relaxes his ban on saying that a thing is its matter. Very occasionally (in another kind of context, and for another purpose) he even lets us say that a thing is one with its matter (or rather he says that this way of speaking is 'better' than certain others he has been describing, which need not mean that it is in every respect alright, G. E C. 320b12-14; cf. Phys. 190a15-16). But the important point is that he also has strong reasons against saying that anger is identical with, or one with, a physiological process. And this differentiates him from the modern materialists we mentioned.

There are other contrasts too. Aristotle would not agree that perception is simply a physiological process. For this 'simply' (Slakey's word) would ignore the formal cause. A house is not simply bricks; it is also a shelter. And this further description is a very important one. Indeed, the formal description of perception is, if anything, more important than the material description. For the body exists for the sake of the soul, in the sense that there would be no point in the existence of bodies and bodily processes, but for the existence of souls and soul states $\left(D A 415^{\mathrm{b}} \mathrm{I}_{5}-2 \mathrm{I}\right)$. A ristotle would reject the view of some materialists ${ }^{46}$ that talk of sensations or houses could be replaced by talk of physiological processes or bricks, without impairing our ability to describe and explain. Formal descriptions cannot be replaced by material descriptions in this way.

43 Metaph. 104Ibr2-I6. Cf. also 1035a7-10, 'the form, or the thing insofar as it has form, should be said to be the thing, but the material by itself should never be said to be so'. Presumably, in the case of anger, the physiological process can occur in sleep, without anger occurring, just as bricks can exist, when a house does not.

44 David Wiggins, Identity and Spatio-Temporal Continuity (Blackwells, 1967), pp. ro-25.

45 Descartes says in the and Meditation that he is a mind, and in the 6th that he has a body. But he also says in the 6th Meditation, and elsewhere, that he is composed of (compositus, composé) mind and body.

46 See Richard Rorty, 'Mind-Body Identity, Privacy, and Categories', The Review of Metaphysics (1965). 
It should now be clear why Aristotle disapproves of Empedocles and Democritus for making perception into a mere qualitative change (Metaph. roogbr3). It also should be clear how we are to interpret the statements quoted earlier where Aristotle seems to talk as if perception or images were physiological processes. They are indeed physiological processes in a way, but only in a sense of 'are' which does not mean 'are identical with', and with the proviso that they are not 'simply' physiological processes.

Aristotle's use of the matter-form distinction in his psychology has been called a strain, a misfit, and an obfuscation. ${ }^{47}$ But it has the merit of steering us away from the idea that mental states may be identical with, or may be simply, physiological processes.

(viii) What is the formal cause of desire? A certain question now becomes urgent. We have seen that anger and smelling are not 'simply' physiological processes. But we have also seen that, whatever else they are, the something else cannot be a further component. Nor can it be a Cartesian act of mind. What else, then, can anger and smelling be? The further description should presumably be parallel to the description of a house as a shelter.

Aristotle tells us that anger can be further described as a desire to retaliate, and smelling as an awareness of odour ( $D A 403$ a25-b9; 424 bi 7 19). But neither answer is very helpful to people with our interests. For the new terms, 'desire' and 'awareness', are, like the original terms ('anger and 'smelling'), the names of pathe of the soul. They therefore invite the same question all over again, "What else are desire and awareness, besides physiological processes?' We would like a description that differs in kind, and is not simply the name of a pathos. Unfortunately, Aristotle has not addressed himself to this question. In what follows we can do no more than ask whether what he says provides the materials for an answer. I propose to take the example of desire.

On the material description of desire we are well informed. According to Mot., chh. 6-10, it is a process of heating or cooling, which results in expansion or contraction of the gaseous stuff called connate spirit, and of the organs, and hence eventually leads to limb movements. The change of temperature involved in the desire to retaliate is not a second physiological process additional to the boiling of the blood around the heart (the material cause of anger). 'Change of temperature' is simply a more general description of the same process.

But what is the formal description of desire? Aristotle places a strong emphasis on the connexion between desire and action. One of the most

47 W. F. R. Hardie, 'Aristotle's Treatment of the Relation Between the Soul and the Body', The Philosophical Quarterly (1964), pp. 64-66; Jonathan Barnes, op. cit., p. 107. 


\section{Richard Sorabji}

interesting passages is the analysis of abilities in Metaphysics $I X$. 5. After analysing non-rational abilities, such as the ability of fire to burn, he passes on to rational abilities such as the ability to heal. These latter are connected with desire. Thus one who is able to heal under appropriate conditions necessarily (1048a 4 ) will heal, if (a) he wants to, (b) of the two results, healing or withholding health, this is the one he wants predominantly, (c) he is in the appropriate conditions (e.g. he is in the presence of the patient, the patient is in a suitable state, and there are no external obstacles to action). ${ }^{48}$ Although Aristotle's interest is in the notion of ability, his account commits him to a certain view of desire. For it implies that if a man desires to heal, and the desire to heal predominates over any desire to withhold health, then necessarily he will heal, provided (i) he has the ability to heal under appropriate conditions, and (ii) he is in those conditions.

A similar view is expressed in Aristotle's account of akrasia or weakness of the will ( $N E$ I 145a I 5-1 1 52a36). He distinguishes between two kinds of weak-willed man. One such man has not deliberated at all ( $N E$ I I 50big-22; I 5 IaI-3; I 152aig; a27-8). But one has deliberated about the best means to achieve his ends, for example about how best to keep fit. And having decided that a diet of chicken is the best means, he has come to want a diet of chicken. 49 The discussion, then, presupposes a man who desires some end, such as health, has worked out the best means to it, and desires to pursue that means. A man with such a desire, we are told, will necessarily (1 147a27; 330) act accordingly and take some chicken, provided that (i) he has the ability ( $1 \mathrm{I}_{47} \mathrm{a} 3 \mathrm{O}$ ), (ii) he is not prevented (I $147 \mathrm{a} 30-3 \mathrm{I}$ ), (iii) he is fully aware of the relevant observational facts (II47a25-26; a29-30; b9-12), such as 'this is chicken', (iv) he links these facts to the fact that eating chicken is good for health ( $11_{47} 7_{226-27}$ ). Aristotle has added in (iii) and (iv) two extra conditions that were not mentioned in the Metaphysics. But the upshot of the two passages is the same, namely that, in certain

48 For a modern version of this analysis, see Nowell-Smith, Ethics (Pelican, I954).

${ }_{49}$ Thus he is described as having deliberated, and as having formed a desire (prohaeresis) based on this deliberation, but as not abiding by his deliberation and his desire (NE II45bII; I148a9; I150br9-22; b30-31; 1151a2; a7; a26; a30-35; b26; 1152a17; a18-19; a26; a28). The chicken example is derived from I I 4 I bi 6-21. For the meaning of prohaeresis see $N E$ I I I 2a I 8-I I I 3a I4, where it is described as a desire for something in one's power (and having a chicken diet is presumably in one's power), which one has calculated to be the best means for achieving one's end. Desire (boulessis) for the end is attributed to the weak-willed man at $1136 \mathrm{~b} 7 ;$ i $166 \mathrm{~b} 8$.

One should not be put off by the statement that the weak-willed man acts without exercising prohaeresis (IIIrbI4; I148aI7). This only means that when he incontinently seizes beef-steak, he has no prohaeresis for beef-steak. He still has his prohaeresis for chicken. 
circumstances, desire necessarily (ro48a14; 1 I47a27; a30) ${ }^{50}$ leads to action.

Aristotle links desire and action again, when he says ( $N E$ II 39a3I-32) that the efficient cause of praxis (deliberate action) is prohaeresis (a certain kind of desire). More generally, the efficient cause of animal motion is desire. 51 Neither these, nor the preceding, statements are offered as providing an analysis of desire. And in some cases the link between desire and action will be more indirect than that described here. For example, Aristotle distinguishes between boulessis, desire for an end such as health, and prohaeresis, desire for something in our power which we have calculated to be the best means (in our earlier example, desire for a diet of chicken). Desire for the end, coupled with calculation, is said to be the efficient cause of desire for the means. And it is only desire for the means which is directly an efficient cause of action ( $N E$ Ir39a3I-33). Desire for the end, Aristotle explains, may be directed towards things which are not immediately in our power, such as health, or towards things which we can't bring about by our own efforts, such as victory for some athlete, or even towards things altogether impossible, such as immortality ( $N E$ I I I Ib I9-30).

Perhaps we now have the materials for conjecturing what Aristotle might say, if asked for the formal description of desire. Would part of his answer be that desire is, in certain conditions, a necessitating efficient cause of action? By 'action' I mean not merely praxis, deliberate action, which is confined to humans, but the various doings of humans and animals. The statement of conditions would include such provisos as that action is in our power, and that we are fully aware of the relevant observational facts. This could not be more than part of Aristotle's answer. ${ }^{52}$ Another part would be

50 It would be anachronistic to ask whether the necessity is logical or physical, for Aristotle does not regard these as distinct kinds of necessity (Sorabji, 'Aristotle and Oxford Philosophy', American Philosophical Quarterly (1969)). The De Motu Animalium provides physiological grounds for postulating a necessity, while Metaphysics IX. 5 provides conceptual grounds, grounds, however, which relate to the concept of ability, rather than to the concept of desire.

51 The efficient cause of animal motion is the soul ( $D A 4$ 15bro; b2I-22). It becomes clear that it is in particular one capacity of the soul, the capacity for desire ( $D A$ III 9-10). The De Motu Animalium 6-10 explains the physical mechanism by which desire leads to action.

52 It is a commonplace to contrast Aristotelian explanations as teleological with Galilean explanations as causal (see e.g. Georg Henrik von Wright, Explanation and Understanding (Routledge, 1971), ch. I; Charles Taylor, The Explanation of Behaviour (Routledge, 1964), ch.1). Certainly, Aristotle favoured teleological explanations, but we should not forget (von Wright, p. 92; Taylor, pp. 4, 20-25) that he thought teleological explanations compatible with explanations by reference to efficient cause. An action, for example, has some end as its final cause, and some desire as its efficient cause. Efficient causes, unlike Humean causes, can be logically related to their effects; it is best to specify the efficient cause of a building as 'the art of building', or failing that, at least as 'a builder', rather than as 'Mr Smith' (Phys. 195a32-b3; b21-25). 


\section{Richard Sorabji}

that every desire has a final cause ( $D A$ 433ar 5$)$. This is the object of desire. And desire, like other activities of the soul, must presumably be defined

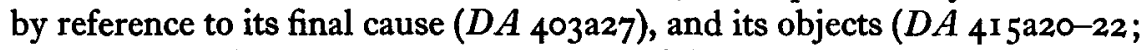
$4^{18 a 7-8)}$. Putting this together, we get a fuller, though no doubt still an incomplete, answer to our question, 'what else is desire, besides a process of heating or cooling?' The answer is that desire has an end, and is, in certain conditions, a necessitating efficient cause of our acting towards that end.

If this conjecture is accepted about the formal description of desire, we can draw conclusions for anger, which is a kind of desire. Anger will be not only a physiological process, but also an efficient cause of retaliation. And we can draw conclusions also for certain other pathē of the soul. For loving and hating are listed as pathe in the Rhetoric, and are there treated like anger as being desires $\left(138 \mathrm{ob}_{35} ; \mathrm{I}_{3} 8 \mathrm{2a}\right.$ 8). They are wishes for good or for harm towards another person. We can expect, then, that they will be efficient causes of corresponding actions.

Our expectation that loving will be connected with action is confirmed in the Rhetoric passage. For Aristotle describes loving not only as wishing good to another person, but also as being a doer of good to him, so far as possible ( $\left.1380 \mathrm{ob}_{35}\right){ }^{53}$ But there is something here that we did not quite expect. Aristotle does not say that loving is an efficient cause of doing good to someone. He says that it is being a doer of good to him, i.e. presumably, it is a tendency to do good to him. Modern discussions have suggested that there is a big difference between a mere tendency to do good and an actual cause of doing good. Perhaps Aristotle does not see a distinction here. We shall return to this question shortly.

Though loving is classed as a pathos in the Rhetoric, friendship is assimilated to a hexis, or long-term state, in the Nicomachean Ethics (1 57 b29). For the difference between pathos and hexis, see note 21. It need be no less true of hexeis than of pathe that some are connected with action. Examples of hexeis are the virtues and vices discussed in the Nicomachean Ethics. And these are connected not only with pathë, but also with action, according to $N E$ I 1 $06 \mathrm{~b}_{23}-28$. For example, hot-temper is not only a matter of being ill disposed in relation to the pathos of anger. It also manifests itself in action in various ways. Consequently, a large number ${ }^{54}$

${ }^{53}$ Similarly, kindness (Rhet. I385ar6) is defined by reference to action, as that in accordance with which a person is said to render a kindness.

54 Courage, Liberality, Magnificence, Great-Souledness, Friendliness, Truthfulness, Ready wit, Justice, and the corresponding vices. Also Self-indulgence, Hot temper, Friendship, Technical skill, Practical wisdom.

There is a class of virtues (friendliness, truthfulness, ready wit) in connexion with which Aristotle deliberately plays down the role of emotion and emphasizes the role of action. See $N E$ I 108a9-31; 1 126bi 1-1 128b9 (esp. 1 126b22-23), and William Fortenbaugh, 'Aristotle and the Questionable Mean-Dispositions', Transactions and Proceedings of the American Philological Association (1968). 
of the virtues and vices are analysed by reference to action, and not, or not only, by reference to pathe. In many cases, hexeis and dunameis (capacities) are described not as mere tendencies to act, but as efficient causes of action, and as things 'from which' and 'through which' we act. ${ }^{55}$

If we have not gone too far beyond Aristotle's text, in our speculations, we now have some sort of answer to our question. The answer will only apply to desire and to some pathe or hexeis of the soul. For Aristotle shows no interest in connecting all pathē or hexeis with action towards an end. But at least for desire we can suggest a formal description which is not merely the name of another pathos. ${ }^{56}$ The description is that desire has an end and is (with appropriate qualifications) an efficient cause of action towards that end. If this is the sort of thing that Aristotle would say, we can now understand how he can hold that desire is something else besides a physiological process, without thinking that the something else is a further component, and without thinking that the something else, or the desire itself, is a Cartesian act of mind. ${ }^{57}$ Our suggested further description of desire is rather like the description of a house as a shelter, in that it does not name either a component or a Cartesian act of mind.

(ix) The analogy with plant growth and elemental motion. We can now return to the point made earlier that Aristotle stresses the continuity between processes in plants and processes in humans. Desire is treated as parallel to the growth of a plant. Neither is called mental. But just as the growth of a plant is not simply a physical process, but also a development towards an end, so desire is not simply a physical process, but also an efficient cause of action towards an end. We can also see more clearly the analogy between desire and the nature of the lifeless elements. Just as desire is an efficient cause of action towards an end, so the nature of a stone, according to the conception of nature in Phys. II. I, is an internal cause of its moving downwards towards an end.

55 See e.g. Phys. 195a5-1 I b23-24; Metaph. 1orgar 5-1020a6; NE I I29a6-21 ; I143b26; $G A$ 726b2r; Rhet. r366b9; $D A$ 4r 5 bro; b21-22.

56 This is not to deny that the notions of having an end, or of acting towards an end, might turn out to involve some indirect reference to pathe of the soul. And we have not made a positive suggestion as to how these further pathe might be analysed. But we have said enough to show how Aristotle could analyse desire without making it, or its formal cause, into a Cartesian act of mind, and without making its formal cause into a component.

57 D. M. Armstrong ( $A$ Materialist Theory of the Mind (Routledge, 1968), pp. II-I2) and Barnes (op. cit.) ascribe to Aristotle the view that, insofar as man has a soul, he has some non-physical attributes. Is desire, as here defined, a nonphysical attribute? Once we observe that it is at any rate not a mental attribute, by Cartesian criteria, the question loses much of its interest. 


\section{Richard Sorabji}

(x) The contrast with Ryle. We must ward off a final danger. We have seen that in his divergence from Descartes, Aristotle does not side with the materialists, nor with Strawson. But it may now appear (and it has been suggested in recent literature) ${ }^{58}$ that Aristotle takes the same path as Ryle, for Ryle, like Aristotle, stresses the links between mental states and action. This would be a mistake for at least two reasons. First, Aristotle has no general programme for analysing mental states by reference to action. He makes the link only in some cases. Secondly, in The Concept of Mind, Ryle analyses many mental states as dispositions or tendencies to act, and he argues that dispositions or tendences are not causes of action. D. M. Armstrong opposes Ryle in $A$ Materialist Theory of the Mind (pp. 85-88). He claims that a disposition necessarily has a 'categorical' basis (cf. Aristotle's boiling of the blood around the heart), with which it can be identified (Aristotle would reject the talk of identification). It is, Armstrong says, in virtue of the categorical basis that the disposition can be a cause of action. While Aristotle would not entirely side with either party in this controversy, some of what he says is closer to Armstrong. For he does speak of desire, and of various hexeis and dunameis, as efficient causes of action. And he might well agree that desire is an efficient cause of action partly because of its physiological basis.

(xi) It is tempting, when Aristotle says that anger and smelling are something else besides a physiological process, to suppose that the something else can only be a Cartesian act of mind. Conversely, if one notices that he postulates no such act of mind, it is tempting to suppose he must be a materialist. If one notices that these are not the only possibilities, the next temptation is to hunt among other current anti-Cartesian views, and to try and match Aristotle with one of them (with Ryle's or Strawson's perhaps). But so long as commentators hope to fit Aristotle into pigeonholes of more recent make, they will continue to come out with such widely divergent interpretations as the ones we noted at the beginning.

\section{PART II : Implications for modern philosophical problems}

Aristotle's view of the body-soul relation has implications for various modern problems. Some of these problems arise for Aristotle only in a different form, and some do not arise at all. They do not arise for a number of reasons, as we shall see, but often because Aristotle's view of the bodysoul relation prevents them from arising.

58 See A. R. White, The Philosophy of Mind (Random House, r967), pp. 46-49, '... to possess some knowledge is to have a tendency or an ability to behave in certain ways'. 
(i) One problem that has troubled modern philosophers is the problem how a mind can possibly move a body. On Descartes' view, as we have seen, this involves interaction between two things that have no 'affinity' with each other. Aristotle is interested in the method by which the soul moves the body. In Book I of the De Anima, he attacks accounts which make the soul into a gas, or other kind of spatial entity, that moves the body by pushing or pulling. Aristotle's biological concept of the soul is not, as we have seen, the same as modern concepts of mind. But he comes fairly close to modern preoccupations in the Physics, when he worries about how the soul can move the body conformably with his principles of causation.

One such principle is the time-honoured requirement, first explicitly formulated by Aristotle himself, of no action at a distance. ${ }^{59}$ In Aristotle's version, the principle says that what acts and what is acted on must be in contact. This in turn is interpreted as meaning that they must have their extremities or edges together. And 'together' is glossed as 'in one immediate place' (Phys. 226b21-227a7). But if a soul is not corporeal ( $D A$ 414a20), nor spatially extended ( $\left.D A 4^{\circ} 7^{\mathrm{a} 2}-3\right)$, it can have no edges. So how can it act on a body? Instead of concluding, like the Epicureans and Stoics, ${ }^{60}$ that since body and soul do interact, the soul must be corporeal, Aristotle appears to be embarrassed into modifying his requirements of contact. At any rate, we find him suddenly switching at Phys. 243a3-6; a32-35 to the weaker principle 61 that what acts and what is acted on should be together, which is explained as meaning that there should be nothing in between them. There is no reference to contact or to edges. And when we ask why not, we notice that he is going on to discuss the case of animals who move themselves $(243$ aI I-15; a2I-23). Now that his requirement is weakened, he is able to say that animals satisfy it. For what acts (and I take it he means the soul) is together with what is acted on (and I take it he means the body), since the former is, in a certain sense, in ${ }^{62}$ the latter, so

59 Phys. III.2, 202a6-9; VII. 1, 242b24-27; b59-63; VII.2; G. \& C. I.6. For the history of this variously interpreted principle, see Mary B. Hesse, Forces and Fields, The Concept of Action at a Distance in the History of Physics (Nelson, 196r).

${ }^{60}$ See Lucretius De Rerum Natura III.161-167. Cleanthes (Nemesius, De Nat. Hom., p. 33, in von Arnim's Stoicorum Veterum Fragmenta 1.518). Iamblichus (quoted in Simplicius' commentary on Aristotle's Categories, ed. Kalbfleisch, pp. 302, $28 \mathrm{ff}$ ).

61 For a different improvised attempt to weaken the principle, by reference to a special kind of touching, see Phys. 258azo, with further explanation at $G . E^{\circ} C$. 323a25-33.

62 In a weak sense of 'in', for the soul does not meet Aristotle's requirements for 'being in a place' ( $D A$ 406a12-r6). And this is presumably why reference to being in a place is dropped from the modified principle. 
that there is nothing in between them. Once again, ${ }^{63}$ the Physics account of the soul seems to involve hasty improvisation.

By the time he came to write the De Anima, Aristotle would have had the means for showing how the stronger contact requirement is satisfied. And he might also have been in a position to answer modern perplexities about the mind moving the body, if he had further exploited his semi-physiological analysis of desire. Desire, as we have seen, is a physiological process of heating or cooling. And it is not philosophically puzzling how heating or cooling, by causing expansion or contraction, can lead to bodily movement. The details of the mechanism are given in Mot. chh. 6-10. At no stage does the process violate Aristotle's requirement of contact, and at no stage do we have the Cartesian problem of interaction between two things that have nothing in common. That desire should cause movement is no more (and no less) puzzling than that heating around the heart should cause expansion. But if desires lead to movement, then there is a sense in which the capacity for desire is responsible for movement. And this in turn means that the soul is responsible for movement. For, as we have seen, the soul is a set of capacities, such as the capacity for desire. ${ }^{64}$

Admittedly, in appealing to heating or cooling, we have not given a complete account of how the body is moved. For all non-compulsory animal motion is for an end ( $D A+32 \mathrm{br} 5)$. If we want a full explanation of animal motion, we shall have to appeal to this end, which is the object desired. But the end is a final, not an efficient, cause. So it does not raise the Cartesian problem of one thing acting as efficient cause upon another with which it has no affinity. Nor does it violate Aristotle's contact requirement, for this requirement too applies only to efficient causation (cf. G. Eீ C. 323a25-33).

(ii) We have been talking about how the soul acts on the body. But there is also a problem for modern Cartesians about how the body acts on the soul. How can a physical process in the eye lead to seeing? W. D. Ross (loc. cit., see above n. 6), speaking of the physical process in the eye, says, 'it does nothing to explain the essential fact about perception, that on this physical change supervenes something quite different, the apprehension by the mind of some quality of an object'. Earlier on the same page, he speaks of 'the distinctively mental, non-corporeal nature of the act', and of 'a purely mental activity having nothing in common with anything physical'. For Aristotle, however, there is no question of how an act in the body can lead to a purely mental activity. For one thing, 'lead to' is not the

$63 \mathrm{Cf}$. the attempt to distinguish animal motion from elemental motion Phys. 255a5-20; b30-31, referred to above, note 15 .

${ }_{64}$ On the different view, according to which the soul is the person who has capacities (see note 7), to say that the soul moves the body is to say that the person moves his body. 
right description, he would say, of the relation between the physical process and the apprehension of colour. Bricks do not 'lead to' a shelter, though they are necessary ( $D A 4_{403}^{\circ} b_{3}$; Phys. II.9), if a shelter is to be realized. ${ }^{65}$ For another thing, it is not a purely mental activity for which the physical process is necessary, either in the case of seeing, or in the case of desire. The physical process is necessary for the realization of the formal cause. In the case of desire, we suggested, the formal cause is not a purely mental activity, but is having an end and being an efficient cause of action towards that end.66

(iii) Aristotle's comparison of anger with a house has implications also for present-day questions about the predictability of states of mind. If I can predict what bricks there will be in the world, it does not follow that I can predict whether there will be houses. For that, I should need to know at least how the bricks were arranged, and perhaps also that the arrangements had at some time been used, or intended for use, as shelters. Equally, if I predict what physiological processes will be going on, it does not follow that I can predict whether people will be angry.

(iv) Throughout the discussion so far, we have been guilty of an oversimplification. For we have spoken as if Aristotle were giving a purely physiological description, with no implications for the mind, in his talk of the boiling of the blood around the heart. But in fact he is so impressed by the importance of a thing's function, that he believes a non-functioning heart, or non-functioning blood, is not a heart, or blood, in the proper sense of the word. This theory is applied to the body as a whole, and to many of its components. ${ }^{67}$ So his description of the physiological process

65 Similarly, heating and cooling (even if they lead to action) do not lead to an efficient cause of action, but are merely necessary for the realization of that cause

66 The formal cause of seeing will be awareness of colour, if seeing is to be treated in the same way as smelling (see p. 70). But the awareness is again not a Cartesian act of mind.

67 See $G A$ 726b22-24; 734b25-27; 735a8; Metaph. 1035br6-17; b24-25; Io36b30-32; DA 412b2o-25; PA 640b34-641a7; Meteor. 389b3I-39ob2; Pol. 1253 a20-22.

Aristotle thus gives to the heart or eye a treatment that would be more appropriate for a scrap of paper used as a bookmarker. The scrap becomes a bookmarker, when so used, and ceases to be a bookmarker, when discarded. When it lies in the wastepaper basket, there is nothing distinctive to connect it, rather than thousands of other objects, with bookmarking; its use alone made it a bookmarker. Contrast the severed hand or eye. This still has a distinctive structure to connect it with its former activities, and so it should still (pace Aristotle) qualify as a hand or eye in the primary sense. This is not to say that structure alone, unconnected with function, can make something an eye in the primary sense. The eye of a peacock's tail is not. For an alternative treatment of Aristotle, see Ackrill, 'Aristotle's Definitions of Psuche', Proceedings of the Aristotelian Society (1972-1973), pp. 127-128. 


\section{Richard Sorabji}

implies a functioning heart, i.e. one that works as the seat of sense-perception, desire and nutrition. It excludes the 'heart' of a corpse.

The theory has implications for another philosophical problem. If true, it would mean that the sceptic who doubts his knowledge of other minds cannot express his doubts by saying, 'I see many eyes around me, but I do not know whether they see. I see many bodies, but I cannot tell whether they feel.' According to Aristotle, in admitting the existence of eyes and bodies, he is admitting the existence of sight, which is the function of eyes, and of touch, the distinctive power of animal bodies.

It is interesting to find a similar argument put forward in recent articles by Douglas Long and John Cook. ${ }^{68}$ Long points out that the sceptical doubt is often expressed as a question as to whether certain bodies are associated with minds. He claims that such philosophers as Price, Broad and Strawson have assumed the existence of other bodies in their discussion of the problem. And this assumption, according to Long, already implies the existence of other minds. So much is reminiscent of Aristotle. Long and Cook go further, and suggest that the sceptic cannot even reformulate his position.

It never occurs to Aristotle to raise doubts about other minds. Such doubts would fit very badly with his teleological attitude. If there were many 'eyes' around, but they had no sight, and many 'bodies', but they had no sense-perception, then nature would have acted in vain. For as he says, the body exists for the sake of the soul ( $\left.D A_{4} \mathrm{I}_{5} \mathrm{~b}_{15}-2 \mathrm{r}\right)$. There would be no point in the existence of bodies, if there were not souls.

For Aristotle, seeing is, among other things, a physiological process, the coloration of the eye-jelly. And this process can in principle, even if not in practice, be observed by others. So there is an answer to the question how one can possibly know that another person is seeing. One can in theory observe the fact. Perhaps it will be objected that to observe the coloration of another man's eye-jelly is to observe only the material cause of his seeing, not the seeing itself. But this objection fails to do justice to Aristotle's position in two ways. First, in Aristotle's view, it is by this means that one is aware of one's own seeing (pp. $7 \mathrm{I}-72$ above). One perceives its material cause, the coloration of the eye-jelly. Secondly, it should not be supposed that after one has observed the physiological process, there is some purely mental act still waiting to be detected. The formal cause of seeing will not be, and will not involve reference to, a purely mental act, one having no 'affinity' with bodily acts. There are no such acts. If there had been, the sceptical doubt would have been easier to raise. As it is, we have not discussed the formal cause of seeing, but we have suggested that the formal cause of desire is having an end and being an efficient cause of

${ }^{68}$ Long 'The Philosophical Concept of a Human Body', The Philosophical Review (1964). Cook 'Human Beings', in Studies in the Philosophy of Wittgenstein, ed. Winch (Routledge, I969). 
action towards that end. And this is something with regard to which it is (not indeed impossible, but) certainly much harder, to raise a plausible doubt.

Aristotle is so far from entertaining doubts about other minds that, in his discussion of friendship, he almost reverses the sceptical position. Some of the benefits of friendship arise from the fact that it is easier to contemplate others than to contemplate ourselves ( NE I I69b33-35) ${ }^{69}$

King's College, London

69 Abbreviations used:

Cat. Categoriae

Top. Topica

Soph. El. De Sophisticis Elenchis

Phys. Physica

G. $\otimes^{2}$ C. De Generatione et Corruptione

Meteor. Meteorologica

$D A \quad$ De Anima

DS De Sensu

DM De Memoria

Som. De Somno

Insom. De Insomniis
HA Historia Animalium

PA De Partibus Animalium

Mot. De Motu Animalium

GA De Generatione Animalium

Metaph. Metaphysica

NE Ethica Nicomachea

EE Ethica Eudemia

Pol. Politica

Rhet. Rhetorica

Poet. De Poetica

I acknowledge gratefully the helpful comments of Willie Charlton, David Hamlyn, Charles Kahn, A. C. Lloyd, A. A. Long, Norman Malcolm, Malcolm Schofield, and of my students, Bill Hartley and Philippa Mance. The writings which I have found most valuable are:

Charles Kahn, 'Sensation and Consciousness in Aristotle's Psychology', Archiv für Geschichte der Philosophie (1966).

Friedrich Solmsen, 'Antecedents of Aristotle's Psychology and Scale of Beings', American Fournal of Philology (1955).

Friedrich Solmsen, 'Nature and Soul', in Aristotle's System of the Physical World (Cornell, 1960), pp. 95-102.

I am greatly indebted to Solmsen's article in I (iii), and to Kahn's in I (iv). 